\title{
Luteal function during the estrous cycle in arginine-treated ewes fed different planes of nutrition
}

\author{
Casie S Bass, Dale A Redmer, Samantha L Kaminski and Anna T Grazul-Bilska \\ Department of Animal Sciences, North Dakota State University, Fargo, North Dakota, USA \\ Correspondence should be addressed to A T Grazul-Bilska; Email: Anna.Grazul-Bilska@ndsu.edu
}

\begin{abstract}
Functions of corpus luteum (CL) are influenced by numerous factors including hormones, growth and angiogenic factors, nutritional plane and dietary supplements such as arginine (Arg), a semi-essential amino acid and precursor for proteins, polyamines and nitric oxide (NO). The aim of this study was to determine if Arg supplementation to ewes fed different planes of nutrition influences: (1) progesterone (P4) concentrations in serum and luteal tissue, (2) luteal vascularity, cell proliferation, endothelial NO synthase (eNOS) and receptor (R) soluble guanylate cyclase $\beta$ protein and mRNA expression and (3) luteal mRNA expression for selected angiogenic factors during the estrous cycle. Ewes $(n=111)$ were categorized by weight and randomly assigned to one of three nutritional planes: maintenance control $(C)$, overfed $(2 \times C)$ and underfed $(0.6 \times C)$ beginning 60 days prior to onset of estrus. After estrus synchronization, ewes from each nutritional plane were assigned randomly to one of two treatments: Arg or saline. Serum and CL were collected at the early, mid and late luteal phases. The results demonstrated that: (1) nutritional plane affected ovulation rates, luteal vascularity, cell proliferation and NOS3, GUCY1B3, vascular endothelial growth factor (VEGF) and VEGFR2 mRNA expression, (2) Arg affected luteal vascularity, cell proliferation and NOS3, GUCY1B3, VEGF and VEGFR2 mRNA expression and (3) luteal vascularity, cell proliferation and the VEGF and NO systems depend on the stage of the estrous cycle. These data indicate that plane of nutrition and/or Arg supplementation can alter vascularization and expression of selected angiogenic factors in luteal tissue during the estrous cycle in sheep.

Reproduction (2017) 153 253-265
\end{abstract}

\section{Introduction}

The corpus luteum (CL) forms after ovulation and is the primary source of the gestational support hormone progesterone (P4; Niswender \& Nett 1994, Diaz et al. 2002, Niswender 2002, Stouffer \& Hennebold 2015). The $C L$ is a fast-growing tissue due to high rates of cell proliferation and changes within vasculature (Jablonka-Shariff et al. 1993, Reynolds et al. 1994). The CL receives some of the highest blood flow rates per unit of tissue, exhibits a high rate of metabolism and contains parenchymal (e.g., steroidogenic) and non-parenchymal (e.g., fibroblasts, immune cells and vascular cells such as pericytes, smooth muscle and endothelial cells) cells (Reynolds et al. 2000, Grazul-Bilska et al. 2001, Redmer et al. 2001). In fact, vascular cells comprise $40-70 \%$ of the total cell population within the mature $\mathrm{CL}$, and the majority of steroidogenic cells within the $\mathrm{CL}$ are in direct contact with one or more capillaries (Jablonka-Shariff et al. 1993, Reynolds et al. 2000).

Nutritional plane, including either undernutrition or overnutrition, and body weight (BW)/body adiposity influence several female reproductive functions including follicular growth (Diskin et al. 2003, Webb et al. 2004, 2007), oocyte quality (Rhind et al. 1989, Grazul-Bilska et al. 2012), ovulation (O'Callaghan \& Boland 1999) and luteal and endocrine functions (Parr et al. 1987, Abecia et al. 1997, Armstrong et al. 2003, Diskin et al. 2003, Lents et al. 2011, Kaminski et al. 2015).

Arginine (Arg) has been demonstrated to enhance selected reproductive functions including placental and fetal growth in several species (Mateo et al. 2007, Zeng et al. 2008, Luther et al. 2009, Lassala et al. 2010, 2011). In addition, Arg affected ovarian functions such as granulosa and luteal cells secretory activities, follicular survival and/or luteal cell apoptosis in several species (Johnson et al. 1999, Vega et al. 2000, GrazulBilska et al. 2015). Although Arg is a precursor for proteins and polyamines, it is also a physiological nitrogen donor for nitric oxide synthase (NOS), which catalyzes $\mathrm{NO}$ formation. It has been demonstrated that reduced systemic Arg concentration impairs NO production (Morris \& Billiar 1994, Wu et al. 1999, Hallemeesch et al. 2002, Wu \& Meininger 2002). Moreover, several studies have demonstrated that NO 
production catalyzed by eNOS is primarily determined by extracellular Arg bioavailability (Hallemeesch et al. 2002, Rajapakse \& Mattson 2009).

It has been clearly demonstrated that $\mathrm{NO}$ is one of the major regulators of vascular development and angiogenesis within the ovary (Reynolds et al. 2002), and $\mathrm{NO}$ has been implicated in the regulation of luteal function in several species (Vega et al. 1998, Dong et al. 1999, Mitsube et al. 1999, Motta et al. 1999, 2001, Skarzynski et al. 2000, 2003, Jaroszewski et al. 2001, 2003, Hurwitz et al. 2002, Grazul-Bilska et al. 2006). One of the major regulators of eNOS expression, and therefore NO production, is vascular endothelial growth factor (VEGF; van der Zee et al. 1997, Duda et al. 2004). Nitric oxide, in turn, is involved in the regulation of VEGF expression, and thus, angiogenesis (Reynolds et al. 2000, 2002, Beckman et al. 2006). Furthermore, it has been demonstrated that luteal growth and regression, as well as vascularity, are regulated by numerous factors including members of the VEGF, angiopoietins and fibroblast growth factor (FGF) families and the NO system (Friden et al. 2000, Boiti et al. 2002, Hoeben et al. 2004, Beckman et al. 2006, Vonnahme et al. 2006).

We hypothesized that inadequate nutrition (either excess or restriction) would result in negative effects on luteal function, whereas Arg would restore luteal functions as evaluated by P4 concentrations, vascularity, cell proliferation, expression of endothelial NOS (eNOS) and $\mathrm{NO}$ receptor soluble guanylate cyclase (sGC) $\beta$ proteins and mRNA expression of selected angiogenic factors. Therefore, the aim of this study was to evaluate the effects of nutritional plane and Arg treatment on (1) CL number and weight, (2) serum and luteal P4 concentration, (3) $\mathrm{CL}$ vascularity and cell proliferation as measured by protein expression of CD31 and Ki67 respectively, (4) luteal eNOS and sGC $\beta$ protein expression and (5) luteal mRNA expression of eNOS, GUCY1B3, VEGF, placental growth factor $(P G F), V E G F$ receptor (R) 1, VEGFR2, FGF2 and FGF2R during the estrous cycle in sheep.

\section{Materials and methods}

All animal procedures performed were approved by the North Dakota State University (NDSU) Institutional Animal Care and Use Committee (\#A12013).

\section{Animals and experimental design}

Animal treatments, diet composition and experimental design are described in detail by Kaminski and coworkers (2015). Briefly, non-pregnant, non-lactating Rambouillet ewes ( $n=111$, between 3 and 5 years of age and of similar genetic background) were penned individually at the Animal Nutrition and Physiology Center on the NDSU campus. Ewes were stratified by weight and randomly assigned to one of three nutritional plane treatments: control $(C ; n=37)$ received a maintenance diet $(760 \mathrm{~g} / \mathrm{kgBW} /$ day $)$, overfed $(\mathrm{O} ; n=37)$ received $2 \times \mathrm{C}$ and underfed $(\mathrm{U} ; n=37)$ received $0.6 \times \mathrm{C} 60$ days prior to the onset of the estrous cycle (day 0). Ewes were fed their individual diets twice daily at 08:00 h and 15:00 h. Ewes were weighed and body condition score (BCS) was evaluated on a 5 -point scale ( $1=$ extremely thin and 5=obese; GrazulBilska et al. 2012) by the same individual once weekly. Diets were adjusted weekly to ensure that the proper BW and BCS scores were achieved by day 0 of the first estrous cycle and maintained throughout the estrous cycle until completion of experiment. Estrus was synchronized by insertion of a controlled internal drug release device for 14 days. Based on previous results (Grazul-Bilska et al. 2013), approximately $36 \mathrm{~h}$ after CIDR removal, ewes were in estrus and treated as day 0 of the estrous cycle. At day 0 of the estrous cycle, ewes were randomly assigned to Arg or saline (Sal) groups, and intravenous injections of Arg or Sal were initiated at 07:00 h.

\section{Arginine or saline treatment}

Ewes in the Sal treatment group received 5-10 mL three times daily of sterile saline solution, whereas ewes in the Arg group received a dose of $155 \mu \mathrm{mol}$ Arg (Sigma)/kg BW three times daily in $5-10 \mathrm{~mL}$ via a jugular vein cannula as described by Kaminski and coworkers (2015). Ewes received Arg or Sal for 15, 21 or 26 days. Arg or Sal was injected three times daily (07:00, 14:00 and 21:00 h) until tissues collection at the end of experiment. After each injection, $1 \mathrm{cc}$ of heparin solution was placed into the cannula to prevent blood from clotting within the tubing.

\section{Tissue and blood collection}

Ovaries and blood samples were collected at the early and mid-luteal phases of the second estrous cycle and at the late-luteal phase of the first estrous cycle. These luteal stages correspond to day 21, 26 and 15 of Arg or Sal treatment. Blood samples were centrifuged, and serum was stored at $-20^{\circ} \mathrm{C}$ until P4 analysis. Numbers of $\mathrm{CL}$ were recorded, and $\mathrm{CL}$ were dissected from the ovary and weighed. Corpora lutea from each ewe were divided into four portions: the first portion was fixed in 10\% neutral buffered formalin (NBF) for immunohistochemistry, the second portion was fixed in Carnoy's solution for immunohistochemistry, the third portion (approximately 20-50 mg) was immediately frozen on dry ice and stored at $-80^{\circ} \mathrm{C}$ until homogenization in PBS $(100 \mathrm{mg} / 1 \mathrm{~mL})$ and the fourth portion (20-50 mg) was placed in $600 \mu \mathrm{L}$ buffer RLT (Qiagen) in a nuclease-free $2.0 \mathrm{~mL}$ tube and homogenized using a $7 \mathrm{~mm}$ generator on a Polytron homogenizer for 10-15s, and then frozen on dry ice and stored at $-80^{\circ} \mathrm{C}$ prior to RNA extraction.

\section{Progesterone analysis}

Progesterone concentration in serum and homogenized luteal tissue was determined using a chemiluminescence immunoassay (Immulite 1000, Siemens), as previously described (Kaminski et al. 2015). The intra-assay CV was $6.9 \%$ for serum and $5.2 \%$ for luteal P4. 


\section{Immunohistochemistry}

Immunohistochemistry was performed as described before (Grazul-Bilska et al. 2006, 2010, 2011). Briefly, all tissues were sectioned using a Leica rotary microtome (Leica RM 2255) and mounted on poly-L-lysine-treated slides (Thermo Fisher Scientific). Tissue sections were deparaffinized in xylene and rehydrated in decreasing concentrations of alcohol in water and then washed in distilled water. Tissue sections underwent antigen recovery (2100 Retriever, Prestige Medical, Lancashire, England) for $20 \mathrm{~min}$ in a $10 \mathrm{mM}$ sodium citrate buffer with $0.05 \%$ Tween $(\mathrm{pH} \mathrm{6)}$. Slides with tissue sections were allowed to cool at room temperature for $20 \mathrm{~min}$, washed and then blocked with $10 \%$ normal goat serum for $20 \mathrm{~min}$ at room temperature followed by incubation with a specific primary antibody and then with a secondary antibody. Table 1 presents fixatives used, tissue thickness and source and dilution of primary and secondary antibodies for all antigens immunodetected. Tissue sections were cover-slipped using Prolonged Gold with DAPI (Life Technologies).

\section{Image generation and analysis}

Photomicrographs were taken with a Zeiss Imager M2 epifluorescence microscope equipped with Zeiss piezo automated stage and AxioCam HRm camera (Zeiss Inc.). All images were taken from areas where distribution of steroidogenic and accessory cells was uniform; areas with connective tissue were avoided. The percentage of area that exhibited positive fluorescent staining for CD31, eNOS or sGC was evaluated quantitatively with an image analysis system (Image Pro-Plus, Media Cybernetics, Silver Spring, MD, USA) as described previously (Vonnahme et al. 2006, GrazulBilska et al. 2010, 2011, 2013). The labeling index (LI) was calculated as the percentage (\%) of proliferating Ki67-positive cells out of the total number of cells (DAPI nuclear staining) within tissue area. For each $\mathrm{CL}$, three randomly chosen fields were evaluated in each tissue section. Background fluorescence was minimal and was adjusted to the same level for each section by the image analysis system. Data were expressed as the percentage of positive staining out of tissue area within each field.

\section{Quantitative polymerase chain reaction (qPCR)}

TaqMan probe primer sets (Applied Biosystems, Life Technologies) for 8 ovine genes (eNOS3, GUCY1B3, VEGF, PGF, VEGFR1, VEGFR2, FGF2 and FGFR) were used as previously described (Redmer et al. 2005, Grazul-Bilska et al. 2011). Quantifications of total RNA were completed via reading absorbance on a Synergy $\mathrm{H} 1$ Microplate Reader (Biotek). Reverse transcription was utilized to produce cDNA (Quantitect RT Kit, Qiagen), from $1 \mu \mathrm{g}$ of RNA. Gene expression was determined (7500 Fast Applied Biosystem Instrument, Life Technologies) and data were analyzed using the comparative CT method using 18s rRNA as the normalizing gene (Livak \& Schmittgen 2001).

\section{Statistical analysis}

Data were analyzed as a $3 \times 2 \times 3$ factorial including all interactions. Data for BW, BCS, P4 concentration in serum and luteal tissues, $C L$ weights, area of positive staining, labeling index and luteal angiogenic factor mRNA expression were analyzed using general linear model (GLM) procedures of SAS (SAS Institute Inc. 2011, Base SAS 9.3 Procedures Guide, Cary, NC, USA: SAS Institute Inc.). The model included plane of nutrition, Arg vs Sal treatment, phase of the estrous cycle and their interactions. When an F-test was significant, differences between specific means were evaluated by using least significant difference test. Means were considered different when $P<0.05$. Data are expressed as mean \pm S.E.M.

\section{Results}

During nutritional and Arg treatments, $\mathrm{C}$ maintained BW and BCS, $O$ gained $4.1 \pm 1.3 \mathrm{~kg}$, and $U$ lost $15.5 \pm 0.6 \mathrm{~kg}$; for $\mathrm{O}$, BCS increased by $1.1 \pm 0.1$ and

Table 1 Tissue fixation, tissue section thickness and antibodies used for immunohistochemistry to detect CD31, Ki67, eNOS and sGC proteins in the $\mathrm{CL}$.

\begin{tabular}{|c|c|c|c|c|c|c|}
\hline Antigen & Marker of & Fixative & $\begin{array}{c}\text { Tissue } \\
\text { thickness }\end{array}$ & $\begin{array}{l}1^{\circ} \text { antibody source, dilution } \\
\text { and incubation time }\end{array}$ & $\begin{array}{l}2^{\circ} \text { antibody source, dilution } \\
\text { and incubation time }\end{array}$ & References \\
\hline CD31 & Endothelial cell & NBF & $15 \mu \mathrm{m}$ & $\begin{array}{c}\text { CD31 rabbit polyclonal, item \# } \\
\text { ab28364, Abcam Biotech } \\
\text { Company; 1:100; overnight }\end{array}$ & $\begin{array}{l}\text { CF } 633 \text { goat anti-rabbit, item \# } \\
20122-0.5 \text { mL, Biotium, San } \\
\text { Francisco, CA, USA; 1:100; } \\
1 \mathrm{~h}\end{array}$ & Redmer et al. (2013) \\
\hline Ki67 & Cell proliferation & NBF & $5 \mu \mathrm{m}$ & $\begin{array}{l}\text { Ki67 mouse monoclonal, item } \\
\text { \# VP-k452, Vector Labs, } \\
\text { Burlingame, CA, USA; } \\
\text { 1:100; overnight }\end{array}$ & $\begin{array}{l}\text { Alexa } 568 \text { goat anti-mouse, } \\
\text { item \# A110040, Life } \\
\text { Technologies; } 1: 200 ; 1 \mathrm{~h}\end{array}$ & $\begin{array}{l}\text { Grazul-Bilska et al. } \\
\quad(2013,2014)\end{array}$ \\
\hline eNOS & $\begin{array}{l}\text { Endothelial nitric } \\
\text { oxide synthase }\end{array}$ & Carnoy's & $5 \mu \mathrm{m}$ & $\begin{array}{l}\text { Anti-eNOS/NOS III purified } \\
\text { mouse, item \# 610297, BD } \\
\text { Biosciences, San Jose, CA; } \\
\text { 1:250; overnight }\end{array}$ & $\begin{array}{l}\text { Alexa } 647 \text { goat anti-mouse, } \\
\text { item \# A21235, Invitrogen; } \\
1: 200 ; 1 \mathrm{~h}\end{array}$ & $\begin{array}{l}\text { Grazul-Bilska et al. } \\
\quad(2006)\end{array}$ \\
\hline $\mathrm{sGC}$ & $\begin{array}{l}\text { Soluble guanylate } \\
\text { cyclase }\end{array}$ & NBF & $5 \mu \mathrm{m}$ & $\begin{array}{l}\text { Guanylate cyclase } \beta \text { rabbit } \\
\text { polyclonal, item \#160897, } \\
\text { Cayman Chemical; } \\
1: 500 ; 1 \mathrm{~h}\end{array}$ & $\begin{array}{l}\text { CF } 633 \text { goat anti-rabbit, item \# } \\
\text { 20122-0.5 mL, Biotium, } \\
\text { San Francisco, CA, USA; } \\
\text { 1:100; } 1 \mathrm{~h}\end{array}$ & \\
\hline
\end{tabular}


Table 2 Weight of $\mathrm{CL}$, and serum and luteal P4 concentration at the early, mid and late luteal phases of the estrous cycle.

\begin{tabular}{lccc}
\hline Measurement & Early-luteal & Mid-luteal & Late-luteal \\
\hline CL weight $(g)$ & $232 \pm 19^{\mathrm{a}}$ & $513 \pm 27^{\mathrm{b}}$ & $514 \pm 25^{\mathrm{b}}$ \\
$\begin{array}{l}\text { Serum P4 concentration } \\
\quad(\mathrm{ng} / \mathrm{mL})\end{array}$ & $1.2 \pm 0.1^{\mathrm{a}}$ & $2.3 \pm 0.1^{\mathrm{b}}$ & $1.0 \pm 0.1^{\mathrm{a}}$ \\
$\begin{array}{l}\text { Luteal P4 concentration } \\
\quad(\mu \mathrm{g} / \mathrm{g} \text { of tissue) }\end{array}$ & $7.3 \pm 0.5^{\mathrm{a}}$ & $10.5 \pm 1.0^{\mathrm{b}}$ & $6.3 \pm 0.9^{\mathrm{a}}$ \\
\hline
\end{tabular}

a,b $P<0.0001-0.001$; mean \pm S.E.M. with different superscripts differ within a row.

$U$ decreased by $0.5 \pm 0.1$. The pattern of BW and BCS changes was similar to reported by Kaminski and coworkers (2015).

$\mathrm{CL}$ weight was greater $(P<0.0001)$ at mid- and lateluteal phases when compared to early-luteal phase and was not affected by nutritional plane or Arg treatment; therefore, combined data are presented in Table 2 .

Serum P4 concentrations were greater $(P<0.0001)$ at mid-luteal phase when compared to early- or lateluteal phases (Table 2). Concentrations of P4 in luteal tissues were greater $(P=0.001)$ at mid- than early- or late-luteal phases (Table 2). Serum and luteal tissue P4 concentrations were not affected by plane of nutrition and Arg treatment.

The numbers of $\mathrm{CL}$, and thus ovulation rates, were greater $(P<0.05)$ in $\mathrm{O}$ and $\mathrm{C}$ when compared to $\mathrm{U}$ and were not affected by Arg treatment, and therefore, combined data are presented (Fig. 1).

A marker of endothelial cells, CD31 protein, was localized to blood vessels of the luteal tissue throughout the estrous cycle (Fig. 2A). CD31 protein expression was greater $(P<0.0001)$ in the early- compared to mid- or late-luteal phase (Fig. 3), was greater $(P<0.02)$ in Sal than Arg-treated groups and tended $(P=0.1)$ to be greater in $C$ than $U$. For CD31 expression quantification and thus vascularity, a tendency $(P=0.09)$ for nutritional plane, Arg treatment and stage of the estrous cycle interactions demonstrated: (1) less CD31 expression in Arg- than Saltreated ewes in $\mathrm{C}$ and $\mathrm{U}$ at the early-luteal phase; (2) less in $\mathrm{O}$ than $\mathrm{C}$ at the mid-luteal phase for both Arg and Sal

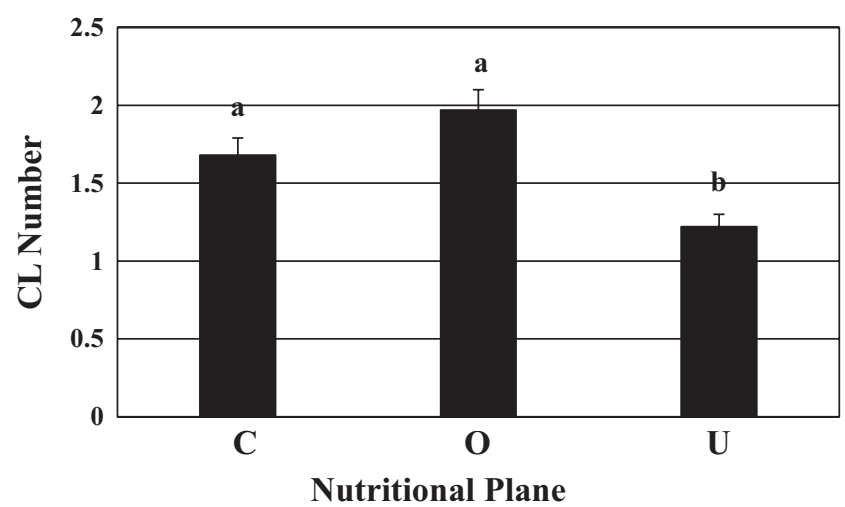

Figure 1 Number of $C L$ in control $(C)$, overfed $(O)$ or underfed $(U)$ ewes. ${ }^{a, b} P<0.05$, means \pm S.E.M. with different superscripts differ.
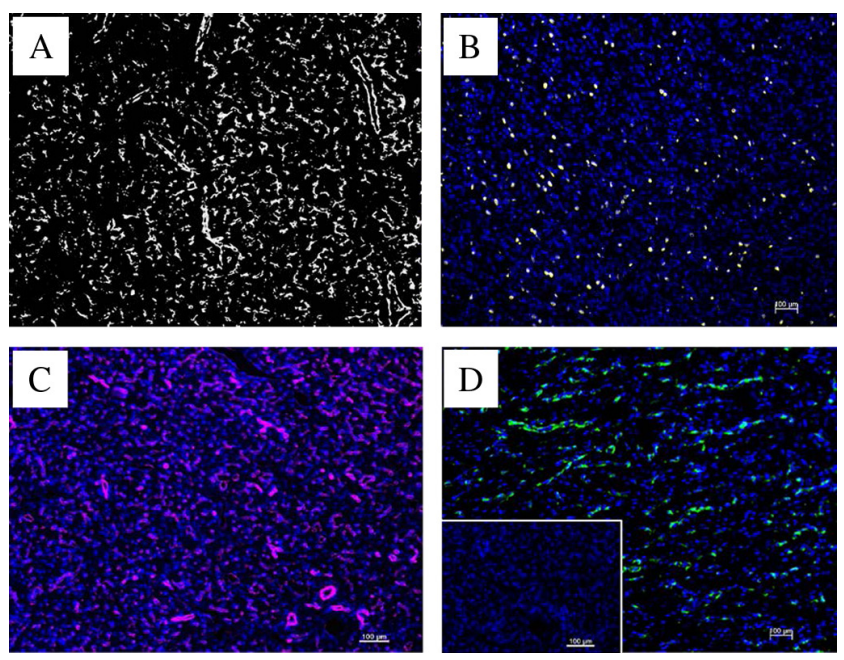

Figure 2 Representative images of immunofluorescent staining of CD31 (A; white), Ki67 (B; yellow), eNOS (C; purple) and sGC (D; green) in luteal tissues from the early-luteal phase of the estrous cycle from Sal-treated control (maintenance diet) ewes. Inset in D represents control, no primary antibody staining. Blue color in each image indicates DAPI nuclei staining. Note expression of CD31, eNOS and sGC in blood vessels. Size bar for all images $=100 \mu \mathrm{m}$.

treatments; (3) less in Arg-treated in $U$ than Sal- or Argtreated $\mathrm{C}$ at the mid-luteal phase; (4) less in Arg- than Sal-treated in $\mathrm{C}$ at the late-luteal phase and (5) less in Arg-treated O or Sal-treated U than Sal-treated C at the late-luteal phase (Fig. 3).

A marker of proliferating cells, Ki67 protein was immunodetected in the nuclei of luteal cells throughout the estrous cycle (Fig. 2B). Labeling index (LI) was greatest $(P<0.0001)$ at the early-luteal phase, less at mid-luteal phase and least at the late-luteal phase (Fig. 4). Interactions $(P<0.05)$ among plane of nutrition, Arg treatment and stage of the estrous cycle demonstrated: (1) greater $\mathrm{LI}$ in Sal-treated ewes in

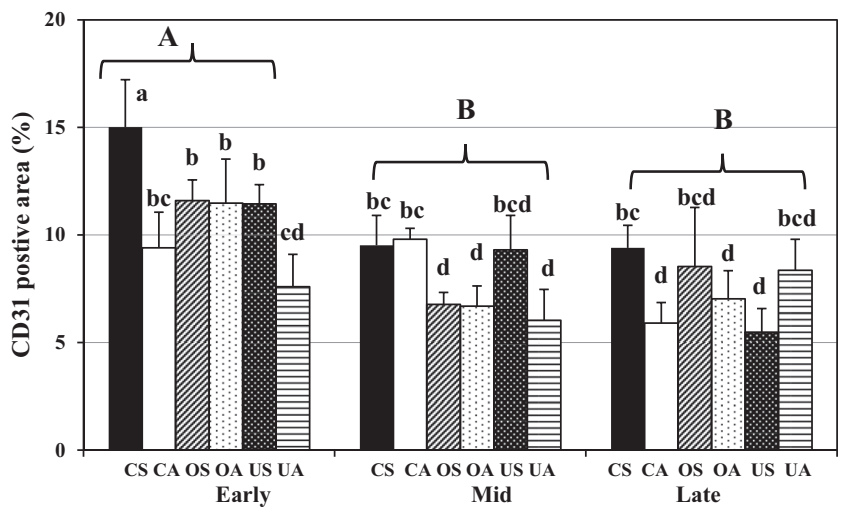

Figure 3 Effects of Arg treatment and plane of nutrition on vascularity measured by CD31 expression in CL from early-, mid- and late-luteal phases of the estrous cycle. ${ }^{a, b, c, d} P<0.09$, means \pm S.E.M. with different superscripts differ; ${ }^{A}, \mathrm{~B}, \mathrm{C} P<0.0001$, overall values with different capital letters differ for early, mid and late-luteal phases. 


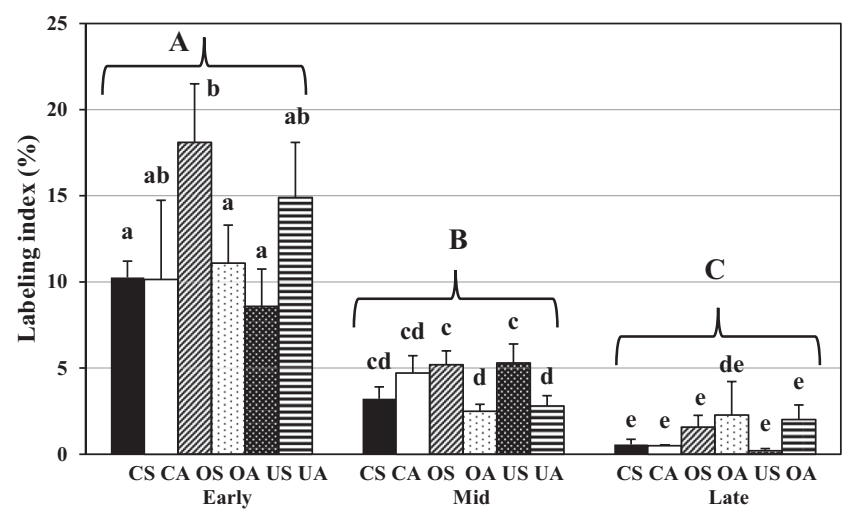

Figure 4 Effects of Arg treatment and plane of nutrition on cell proliferation expressed as labeling index in CL from early-, midand late-luteal phases of the estrous cycle. ${ }^{a, b, c, d} P<0.09$, means \pm S.E.M. with different superscripts (small letters) differ. $A, B, C P<0.0001$, overall values with different capital letters differ for early, mid and late-luteal phases.

$\mathrm{O}$ than $\mathrm{C}$ and $\mathrm{U}$ at the early-luteal phase; (2) lower LI in Arg than Sal-treated $\mathrm{O}$ at the early luteal phase; and (3) lower LI in Arg- than Sal-treated O and U at the mid-luteal phase.

Endothelial NOS protein was immunodetected and localized to blood vessels of the luteal tissue throughout the estrous cycle (Fig. 2C). Expression of eNOS was greater $(P<0.01)$ at mid-luteal compared to early- or late-luteal phases and was not affected by nutritional plane or Arg treatment (Fig. 5).

Expression of NOS3 mRNA tended $(P=0.1)$ to be greater at the early- than mid- or late-luteal phases (Fig. 6A). Interactions $(P<0.04)$ among plane of nutrition, Arg treatment and stage of the estrous cycle demonstrated greater NOS3 mRNA expression in Argtreated $\mathrm{C}$ ewes during the mid-luteal phase than any other group except Sal-treated $\mathrm{O}$ ewes at the earlyluteal phase. In addition, these interactions $(P<0.04)$

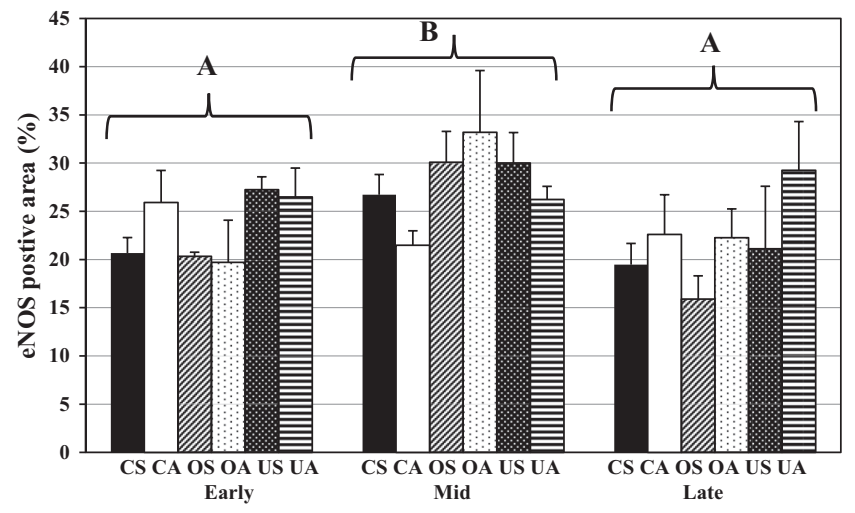

Figure 5 Effects of Arg treatment and plane of nutrition on eNOS protein expression in $\mathrm{CL}$ from early-, mid- and late-luteal phases of the estrous cycle. ${ }^{A, B}, C P<0.0001$, overall values with different superscripts differ for early, mid and late-luteal phases.
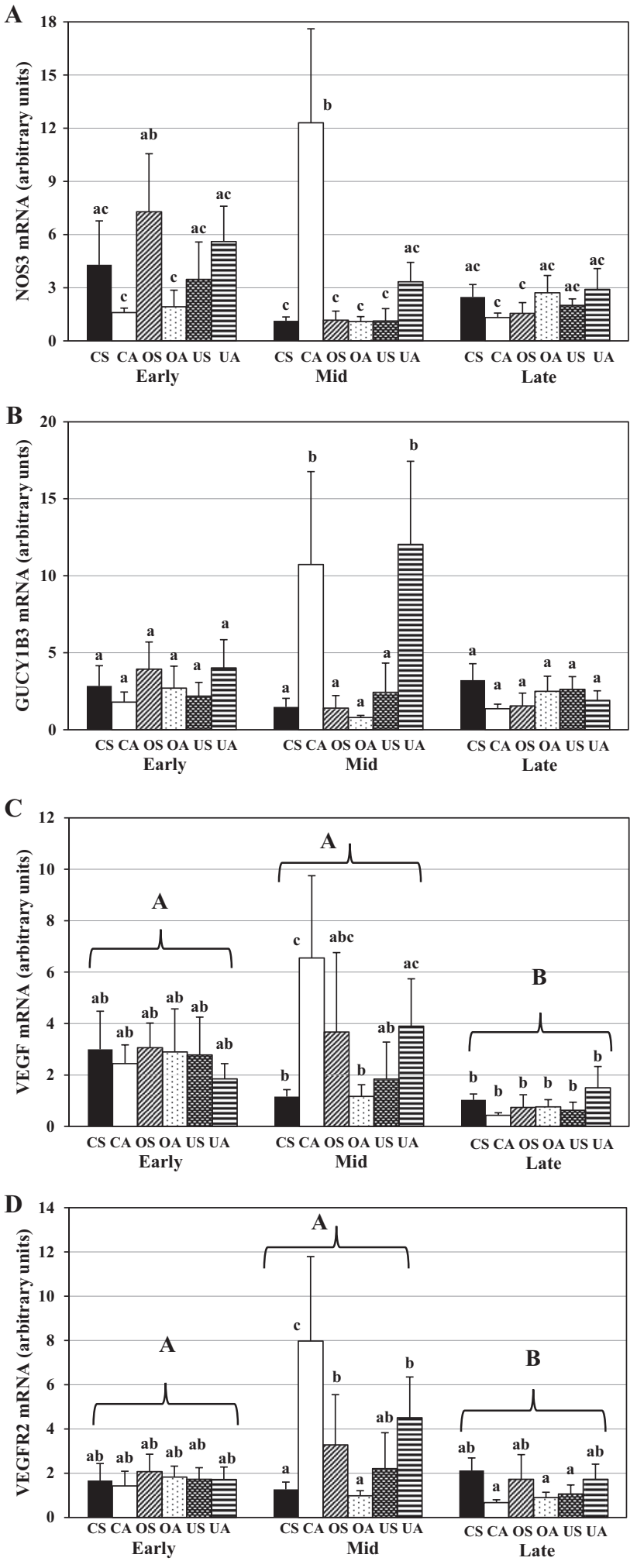

Figure 6 Effects of Arg treatment and plane of nutrition on mRNA expression of eNOS (A), GUCY1B3 (B), VEGF (C) and VEGFR2 (D) in $\mathrm{CL}$ at early-, mid- or late-luteal phases of the estrous cycle. For $\mathrm{A}, \mathrm{B}$ and $C,{ }^{a}, b P<0.05$, means \pm S.E.M. with different superscripts differ; and for $C$ and $D, A, B P<0.0001$, overall values with different superscripts differ for early, mid and late-luteal phases. 
Table 3 Summary of effects of plane of nutrition (control (C), overfed $(\mathrm{O})$ and underfed $(\mathrm{U})$ ), arginine (Arg) or saline (Sal) treatment, and early-, mid-, or late-luteal phases of the estrous cycle, and their interactions on several measurements of luteal function.

\begin{tabular}{|c|c|c|}
\hline Treatments & Measurements* & Observed change \\
\hline \multirow[t]{3}{*}{ Nutritional plane } & Ovulation rate** & Greater in $\mathrm{O}$ and $\mathrm{C}$ than $\mathrm{U}$ \\
\hline & Serum P4 concentrations (tendency) & Greater in $\mathrm{O}$ than $\mathrm{C}$ or $\mathrm{U}$ \\
\hline & CD31 expression (tendency) & Greater in $\mathrm{C}$ than $\mathrm{U}$ \\
\hline \multirow[t]{2}{*}{ Arginine } & Vascularity $(\mathrm{CD} 31 ; * *)$ & Greater in Sal than Arg \\
\hline & GUCY1B3 mRNA (tendency) & Greater in Arg than Sal \\
\hline \multirow[t]{7}{*}{ Stage of the estrous cycle } & CL weight** & Greater in mid and late than early \\
\hline & Serum and luteal P4** & Greater in mid than early or late \\
\hline & Vascularity $(\mathrm{CD} 31 ; * *)$ & Greater in early than mid or late \\
\hline & Labeling index (Ki67; $\left.{ }^{* *}\right)$ & Greater in early than mid and late \\
\hline & eNOS protein** & Greater in mid than early or late \\
\hline & $V E G F \mathrm{mRNA} * *$ & Greater in early and mid than late \\
\hline & VEGFR2 $\mathrm{mRNA} * *$ & Greater in mid than early and late \\
\hline \multirow[t]{6}{*}{ Interactions } & Vascularity (CD31; tendency) & Effects of Arg, nutritional plane and stage of the estrous cycle \\
\hline & Labeling index (Ki67; **) & Effects of Arg, plane of nutrition and stage of the estrous cycle \\
\hline & eNOS mRNA** & Effects of Arg, plane of nutrition and stage of the estrous cycle \\
\hline & GUCY1B3 mRNA (tendency) & Effects of Arg and stage of the estrous cycle \\
\hline & VEGF mRNA (tendency) & Effects of Arg, plane of nutrition and stage of the estrous cycle \\
\hline & VEGFR2 mRNA** & Effects of Arg, plane of nutrition and stage of the estrous cycle \\
\hline
\end{tabular}

${ }^{*}$ Measurements that were significantly $\left({ }^{* *} P \leq 0.05\right)$ or tended $(P \leq 0.1-0.2)$ to be significantly affected are listed.

demonstrated that expression of NOS3 mRNA was greater in Sal-treated $\mathrm{O}$ ewes at the early-luteal phase than: (1) Arg-treated $\mathrm{C}$ and $\mathrm{O}$ at the early-luteal phase, (2) Sal-treated $\mathrm{C}, \mathrm{O}$ and $\mathrm{U}$ at the mid-luteal phase, (3) Arg-treated $\mathrm{O}$ at the mid-luteal phase and (4) Arg-treated $\mathrm{C}$ and Sal-treated $\mathrm{O}$ ewes at the late-luteal phase (Fig. 6A).

Soluble GC $\beta$ protein was immunodetected in luteal blood vessels (Fig. 2D) and expression was similar in all groups (image analysis data not shown) throughout the estrous cycle. GUCY1B3 mRNA expression tended $(P=0.09)$ to be greater in Arg- than Sal-treated ewes, but was not affected by nutritional plane or stage of the estrous cycle (Fig. 6B). Interactions $(P=0.01)$ between Arg treatment and stage of the estrous cycle demonstrated greater GUCY1B3 mRNA expression in luteal tissue from Arg-treated $C$ and $U$ at the mid-luteal phase than in any other group (Fig. 6B).

Expression of VEGF mRNA was greater $(P=0.02)$ at early- and mid-compared to late-luteal phase (Fig. 6C). Tendency ( $P=0.1)$ for interactions among Arg treatment, plane of nutrition and stage of estrous cycle demonstrated greater VEGF mRNA expression in Argthan Sal-treated $\mathrm{C}$ ewes and Arg-treated $\mathrm{O}$ ewes at the mid-luteal phase (Fig. 6C).

Expression of VEGFR2 mRNA was greater $(P<0.02)$ at the mid-compared to early- or late-luteal phases (Fig. 6D). Interactions $(P=0.05)$ among Arg treatment, plane of nutrition and stage of the estrous cycle demonstrated that VEGFR2 mRNA expression was (1) greatest in Arg-treated $C$ at the mid-luteal phase and (2) greater in Sal-treated $\mathrm{O}$ ewes or Arg-treated $U$ ewes at the mid-luteal phase when compared to Sal-treated C, Arg-treated $\mathrm{O}$ at the mid-luteal phase and Arg-treated $\mathrm{C}$ and $\mathrm{O}$ ewes at the late-luteal phase (Fig. 6D).
Expression of $P G F, V E G F R 1, F G F 2$ and FGF2R mRNA in luteal tissues was similar in all treatment groups and stages of the estrous cycle (data not shown).

A summary of obtained results is presented in Table 3.

\section{Discussion}

The present study demonstrates that nutritional plane and/ or Arg treatment affects several measurements of luteal function during the estrous cycle including $\mathrm{CL}$ number (ovulation rates), luteal vascularity, cell proliferation and mRNA expression of NOS3, GUCY1B3, VEGF and VEGFR2.

In our study, ovulation rates were greater in $\mathrm{O}$ and $\mathrm{C}$ compared to $U$. Several studies have previously reported the association between nutritional plane and ovulation rate demonstrating a positive correlation between higher BCS and ovulations rates (Gunn \& Doney 1975, Rhind et al. 1989, Xu et al. 1989, Smith 1995, Abecia et al. 1997), and low ovulation rates in ewes with lower BCS (Keisler \& Buckrell 1997, Lassoued et al. 2004). When an animal is in a negative energy balance, the animal must use its own energy stores in an effort to reverse the energy deficit, resulting in negative effects on both the hypothalamic-pituitary axis, as well as the reproductive system (Scaramuzzi et al. 2006). Additionally, restricted nutritional planes lead to a hormonal imbalance including, but not limited to, elevated plasma growth hormone, the inhibition of gonadotropin-releasing hormone, reduced ovulation rates and may cause anovulation (Scaramuzzi et al. 2006). Furthermore, follicular population and ovulation rates are reported to be very sensitive to nutritional plane alterations in the ewe (Scaramuzzi et al. 2006). Although our results concerning nutritional effects on ovulation rates in ewes are reflective of previous reports $\left(\mathrm{O}^{\prime}\right.$ Callaghan \& Boland 1999), our study demonstrated that ovulation rate was 
not affected by Arg supplementation. Therefore, we hypothesize that Arg is not involved in the regulation of ovulation rate in sheep.

In this study, CL weight, serum and luteal P4 concentration, eNOS protein expression, and VEGF and VEGFR2 mRNA expression were greatest at the mid-luteal phase confirming previous reports and also indicating normal luteal development and function (Stabenfeldt et al. 1969, Niswender \& Nett 1994, Grazul-Bilska et al. 2006). Furthermore, CL weight and serum and luteal P4 concentration were not affected by nutritional plane in our experiment. However, Kaminski and coworkers (2015) observed increased serum $\mathrm{P} 4$ in $\mathrm{O}$ ewes throughout the estrous cycle, and Eborn and coworkers (2014) reported greater plasma P4 concentration in pre-pubertal heifers fed a high-energy diet compared to heifers fed a low-energy diet. In contrast, increased serum P4 concentrations during the first estrous cycle when nutrient intake was reduced in cows (Jordan \& Swanson 1979) and ewes (Cumming et al. 1971) have been reported. However, if cows remain on a restricted nutritional intake, peripheral P4 concentrations are significantly reduced in later, consecutive estrous cycles (Gombe \& Hansel 1973, Beal et al. 1978, Rodrigues et al. 2011). This subsequent decrease in P4 may be attributed to depletion in adipose tissue as it has been demonstrated that a considerable amount of P4 can be stored in adipose tissue and released into circulation if the fat is metabolized (Hamudikuwanda et al. 1996). These findings could explain why serum P4 tended to be lower in $U$ ewes when compared to $\mathrm{O}$ ewes in the present study. Underfed ewes in this study lost $15 \%$ of their initial BW, and thus, fat storage was depleted, as reflected by decreased $\mathrm{BW}$ and $\mathrm{BCS}$.

In the present experiment, Arg did not affect CL weight or serum and luteal P4 concentration at any stage of the estrous cycle. In our previous study, Arg treatment from day 8 to 12 of the estrous cycle also did not affect serum P4 concentration, but affected some but not all measurements of blood flow (e.g., systolic velocity, but not pulsatility index or resistance index, was increased) to the ovarian hilus and the $\mathrm{CL}$ (Saevre et al. 2011a). In contrast, during early pregnancy, Arg treatment from breeding until day 15 enhanced serum P4 concentrations measured as area under curve (Luther et al. 2009). However, when ewes were treated with Arg from day 9 to 14 of early pregnancy, increased serum P4 concentration was observed on days 9 and 10 only (Saevre et al. 2011b). Thus, the effects of Arg on serum P4 concentration, and ovarian and CL blood flow depend on Arg dose, time and length of treatment and reproductive status.

The present study demonstrated that vascularity (marked by CD31 expression) of the luteal tissue was greatest at the early-luteal phase. Similar data of luteal vascularity pattern during the estrous cycle were previously reported for sheep (Jablonka-Shariff et al. 1993), cows (Hünigen et al. 2008) and primates (Fraser et al. 2000). During the early-luteal phase, angiogenesis is quickly progressing to establish a blood vessel network (Reynolds et al. 2000). In fact, $50-85 \%$ of the cells that are present in the growing CL are endothelial cells and pericytes (Christenson \& Stouffer 1996, Reynolds et al. 2000, Redmer et al. 2001). The rapid microvasculature growth rate is critical for proper $\mathrm{CL}$ development and function, and inadequate ovarian blood supply has been associated with abnormal, decreased luteal function (Reynolds et al. 2000, 2002, Grazul-Bilska et al. 2001, Hazzard et al. 2002). Furthermore, decreased vascularity is characteristic for luteal regression during the late-luteal phase (Knickerbocker et al. 1988, Vonnahme et al. 2006).

In the present study, plane of nutrition affected luteal vascularity during the estrous cycle; in the Sal-treated group, at the early-luteal phase, luteal vascularity was less in $\mathrm{O}$ and $\mathrm{U}$ than $\mathrm{C}$, at the mid-luteal phase was less in $\mathrm{O}$ than $\mathrm{C}$ and at the late-luteal phase was less in $\mathrm{U}$ than C. In addition, Arg reduced vascularity at the earlyluteal phase in $C$ and $U$ and at the late-luteal phase in C. Association between diet/body adiposity and vascularity in the $C L$ has not been studied in detail in any species, but existing limited data indicate that plane of nutrition may affect ovarian blood vessel function and improve vascular functions in compromised reproductive conditions. For example, in sheep, we have demonstrated that maternal restricted diet decreased vascular cell proliferation in fetal ovaries by the end of pregnancy (Grazul-Bilska et al. 2009). In obese women with polycystic ovarian syndrome, weight loss improved endothelial functions measured by activity of selected endothelium markers in serum (Thomson et al. 2012) and also improved vascular indices such as blood pressure and small resistance arterial compliance (Moran et al. 2010).

Based on a report that Arg could cause senescence of human endothelial cells in vitro (Scalera et al. 2009, Xiong et al. 2014), we hypothesize that increased Arg concentration caused endothelial cells premature senescence during a period of rapid cellular proliferation and formation of the blood vessel network. Furthermore, as Arg affected luteal vascularity only during the earlyluteal phase, we postulate that rapidly growing $C L$ and proliferating luteal cells including endothelial cells are more sensitive to Arg effects than differentiated or regressing CL. However, decreased vascularity due to nutritional plane or Arg-treatment was not associated with changes in $\mathrm{P} 4$ secretion in this study. Thus, major luteal function was not affected by nutritional plane and Arg. Therefore, additional research is required to elucidate the association between plane of nutrition, Arg and vascular architecture and luteal secretory functions. Interestingly, studies regarding the cardiovascular system have demonstrated improvements of endothelialdependent vasodilation or blood pressure reduction 
after Arg treatment in animal models or patients with cardiovascular disease (Girerd et al. 1990, Cooke et al. 1992, Creager et al. 1992, Clarkson et al. 1996, Palloshi et al. 2004, Dong et al. 2011). We postulate that effects of diet or Arg on vascular function in the $\mathrm{CL}$ and other tissues depend on the length of treatment, diet composition and/or dose.

In this and our previous study, cell proliferation in luteal tissues was greatest at the early-, less at the mid-, and least at the late-luteal phase, which corresponds to luteal growth, differentiation and regression respectively (Jablonka-Shariff et al. 1993). Similar patterns of change in luteal cell proliferation during the estrous cycle were reported for other species including cows and monkeys (Young et al. 2000, Yoshioka et al. 2013). In this study, cell proliferation was also affected by plane of nutrition and Arg treatment depending on the stage of estrous cycle. Very limited data are available concerning the role of diet or Arg in the regulation of luteal growth or regression reflected by cell proliferation and apoptosis for any species. However, available limited data indicate that diet may affect growth and regression of ovarian compartments including the $\mathrm{CL}$ measured by cell proliferation or apoptosis respectively. In our previous studies using sheep, both restricted and excess maternal diet decreased cell proliferation in ovarian stroma but not in the $\mathrm{CL}$ or follicles, but diet-modulated selenium effects on luteal cell proliferation in adolescent ewes (GrazulBilska et al. 2014). Furthermore, restricted maternal diet decreased cell proliferation in fetal primordial follicles and ovarian stroma at the end of pregnancy (GrazulBilska et al. 2009). For rats, high-energy diet enhanced caspase-3 expression in the CL indicating enhanced apoptosis in luteal tissues, and thus, likely reducing growth (Hussain et al. 2016). Data concerning in vivo Arg effects on the $\mathrm{CL}$ growth are not available for any species. However, in vitro experiments demonstrated that Arg inhibited E2 secretion, enhanced luteal cell apoptosis and decreased luteal Bcl-2 (an anti-apoptotic factor) from mid- and late-but not early-luteal phases in humans (Johnson et al. 1999, Vega et al. 2000). It has been hypothesized that Arg can be metabolized to nitric oxide and to polyamines or act directly to activate the mechanistic target of rapamycin cell signaling pathway to stimulate proliferation, migration and mRNA translation in the cell (Bazer et al. 2011). However, this hypothesis should be tested for luteal tissues. Overall, these results indicate that both plane of nutrition and Arg play a regulatory role in luteal growth.

Similar to previous observations in several species, eNOS protein was localized within luteal tissue vasculature in this study (Zackrisson et al. 1996, Jablonka-Shariff \& Olson 1997, Boiti et al. 2002, Al-Gubory et al. 2005, Grazul-Bilska et al. 2006, Zerani et al. 2013). The current data demonstrate that eNOS protein expression was greatest at the mid-luteal phase when compared to early- or late-luteal phases. In contrast to our current results, previous studies have reported greater eNOS protein expression in the $\mathrm{CL}$ from the early-luteal phase in sheep (Al-Gubory et al. 2005, Grazul-Bilska et al. 2006). These differences are likely due to methodological differences including antibody sensitivity, detection technique (fluorescence vs colorimetric) and image analysis. Localization of eNOS protein to luteal vascularity supports previous reports concerning association of the NO system with blood vessel functions.

Although both eNOS and CD31 (marker of endothelial cells) expression were localized to blood vessels, their pattern of expression differed. We hypothesize that CD31 only marks the presence of the vascular bed by binding to endothelial cells and likely does not play any additional role in regulation of blood vessel function in the CL. However, as the NO system is involved in the regulation of $\mathrm{CL}$ function (Motta et al. 1999, Skarzynski \& Okuda 2000, Dixit \& Parvizi 2001, Weems et al. 2005, Beckman et al. 2006, Keator et al. 2008), changes in eNOS expression reflect not only the density of vasculature but also its regulatory role at specific stages of luteal development and differentiation.

In the current study, Arg affected not only luteal vascularity but also eNOS and GUCY1B3 mRNA expression, depending on the stage of the estrous cycle and nutritional plane. Furthermore, nutritional plane exerted very limited effects on eNOS or NOS3 mRNA expression in the CL. Luteal expression of GUCY1B3 mRNA, but not sGC $\beta$ protein, tended to be affected by Arg treatment in our study. Similarly, GrazulBilska and coworkers (2006) reported unchanged GUCY1B3 mRNA expression in luteal tissue throughout the estrous cycle. As Arg is a precursor for many components, including $\mathrm{NO}$, supplementing Arg in excess could enhance NO production that may be reflected in changes of eNOS and GUCY1B3 mRNA expression. In fact, several previous studies have demonstrated that $\mathrm{NO}$ production is primarily determined by extracellular Arg bioavailability in bovine (Hardy \& May 2002) and human (Xiong et al. 2014) endothelial cells and that Arg administration for just $30 \mathrm{~min}$ results in an increase of $\mathrm{NO}$ production (Xiong et al. 2014). Thus, we hypothesize that Arg may directly or indirectly affect the NO system and vascular function in the $\mathrm{CL}$, however, without affecting measurable P4 secretion.

In the present study, VEGF mRNA expression was greatest at the early- and mid-luteal phases, VEGFR2 mRNA expression was the greatest at the mid-luteal phase and VEGFR 1 mRNA mRNA expression remained unchanged during the estrous cycle. In addition, VEGF and VEGFR2 mRNA expression was influenced by nutritional plane and Arg treatment depending on the stage of the estrous cycle. Vascular endothelial growth factor and their receptors are critical regulators of 
angiogenesis, blood vessel permeability and normal blood vessel function (Reynolds et al. 1994, 2000, Ferrara \& Davis-Smyth 1997, Geva \& Jaffe 2000, Grazul-Bilska et al. 2001, Vonnahme et al. 2006). We postulate that during the early-luteal phase, specific expression of VEGF and VEGF receptors is required to initiate and regulate angiogenesis, and during the mid-luteal phase, VEGF may be required to control blood vessel permeability and endothelial cell function. Our findings are similar to a previously reported studies, wherein VEGF and/or receptors were detected in luteal tissues of women (Sugino et al. 2000), sow (Kaczmarek et al. 2007), water buffalo (Papa et al. 2006), cow (Berisha et al. 2000, 2016), mare (Al-zi'abi et al. 2003, Müller et al. 2009), monkey (Fisher et al. 2013) and ewe (Redmer et al. 1996, Vonnahme et al. 2006). Furthermore, increased VEGF mRNA expression during the mid-luteal phase was observed in several species (Al-zíabi et al. 2003, Papa et al. 2006, Müller et al. 2009). Critical importance of the VEGF system for luteal function has been clearly demonstrated as inhibition of VEGF resulted in decreased luteal vascularity, angiogenesis, endothelial cell proliferation and/or decreased P4 (Ferrara et al. 1998, Fraser et al. 2000, Hazzard et al. 2002).

In this study, Arg increased luteal VEGF and VEGFR2 mRNA expression in $\mathrm{C}$ and decreased VEGFR2 mRNA expression in $\mathrm{O}$ at the mid-luteal phase of the estrous cycle, indicating that both diet and Arg are involved in the regulation of these angiogenic factors. In pigs, underfeeding resulted in decreased expression of VEGF and VEGFR-2 mRNA expression in newly formed CL (Galeati et al. 2005). In monkeys, expression of selected miRNA/mRNA involved in the regulation of follicular development, steroidogenesis, granulosa cell proliferation and survival that are associated with the development of a dysfunctional CL was affected by weight gain (Bradford et al. 2015). Limited information is available concerning the role of Arg in the regulation of the VEGF system in the CL of any species. However, it has been demonstrated that in pigs Arg decreased plasma VEGF concentration and increased VEGF mRNA expression in the fetal umbilical vein (Liu et al. 2012), and in mice, increased VEGF serum levels (Fiorito et al. 2008). Additional studies should be undertaken to determine mechanisms of diet and Arg effects on the VEGF system in CL.

Other factors involved in the regulation of tissue growth and/or angiogenesis including PGF, VEGFR1, $F G F 2$ and FGF2R were expressed in luteal tissues in the present study, but their expression was not affected by plane of nutrition, Arg treatment or stage of the estrous cycle. All the above-listed factors have been implicated in the regulation of luteal function, and their expression in the ovine $\mathrm{CL}$ has been previously reported
(Reynolds et al. 1994, 2000, 2002, Jablonka-Shariff et al. 1997, Doraiswamy et al. 1998, Grazul-Bilska et al. 2001, Vonnahme et al. 2006).

Our hypothesis concerning possible Arg effects on nutritionally compromised ewes was based on previous observations for pregnant animals, demonstrating that Arg treatment benefitted ovarian and placental functions and increased the number of offspring born (Mateo et al. 2007, Zeng et al. 2008, Luther et al. 2009, Saevre et al. 2011 b) and offspring body weights (de Boo et al. 2005, Lassala et al. 2010, 2011) in sheep, rats and pigs. However, Arg treatment of nonpregnant ewes, while changing luteal vascularity, did not affect ovulation rate, CL weight or $\mathrm{P} 4$ production. The limited effects of Arg on luteal function in this experiment and endocrine functions in our previous study (Kaminski et al. 2015) may be due to the fact that Arg is a semi-essential amino acid in non-pregnant animals (Wu \& Morris 1998, Wu \& Meininger 2002). Therefore, further research is required to determine potential Arg benefits on other reproductive functions in non-pregnant females as a limitation of this study is in length, timing and dose of Arg used. In our experiment, serum Arg concentration fluctuated throughout each day of treatment from high levels after infusion to basal levels $\sim 4 \mathrm{~h}$ later (Kaminski et al. 2015). However, if serum Arg would be maintained at constant high levels by frequent injections or feeding rumen protected Arg (Saevre et al. 2011a) for a defined period of time, the effects of Arg on luteal functions will likely differ from data presented herein; however, this postulation requires further study.

In summary, we have demonstrated that: (1) nutritional plane affected ovulation rates, luteal vascularity, cell proliferation and NOS3, GUCY1B3, VEGF and VEGFR2 mRNA expression, (2) Arg affected luteal vascularity, cell proliferation and NOS3, GUCY1B3, VEGF and VEGFR2 mRNA expression and (3) serum and luteal P4 concentration, CL weight, luteal vascularity, cell proliferation, and the VEGF and NO systems depend on the stage of the estrous cycle. These data indicate that plane of nutrition and/or Arg supplementation can alter vascularity and expression of selected angiogenic factors in luteal tissue during the estrous cycle in sheep. In addition, our data further support previous observations that the VEGF and NO systems are involved in luteal function throughout the estrous cycle. As plane of nutrition had profound effects on luteal function, our results emphasize the importance of optimal diet to maintain reproductive functions in sheep.

\section{Declaration of interest}

The authors declare that there is no conflict of interest that could be perceived as prejudicing the impartiality of the research reported. 


\section{Funding}

This project was supported by the USDA-AFRI grant 201167016-30174 and Hatch Projects ND01754 and ND01748 to Anna T Grazul-Bilska and Dale A Redmer.

\section{Acknowledgements}

The authors would like to thank Dr Joel Caton for consultations concerning animal diets, Dr Jodi Haring, Dr Sheri Dorsam and undergraduate students for laboratory assistance, and Jim Kirsch, Terry Skunberg, the staff at NDSU Animal Nutrition and Physiology Center, and undergraduate students for assistance with animal care and handling.

\section{References}

Abecia JA, Lozano JM, Forcada F \& Zarazaga L 1997 Effect of level of dietary energy and protein on embryo survival and progesterone production on day eight of pregnancy in Rasa Aragonesa ewes. Animal Reproduction Science 48 209-218. (doi:10.1016/S0378-4320(97)00021-3)

Al-Gubory KH, Ceballos-Picot I, Nicole A, Bolifraud P, Germain G, Michaud M, Mayeur C \& Blachier F 2005 Changes in activities of superoxide dismutase, nitric oxide synthase, glutathione-dependent enzymes and the incidence of apoptosis in sheep corpus luteum during the estrous cycle. Biochimica et Biophysica Acta 1725 348-357. (doi:10.1016/j.bbagen.2005.06.018)

Al-zi'abi MO, Watson ED \& Fraser HM 2003 Angiogenesis and vascular endothelial growth factor expression in the equine corpus luteum. Reproduction 125 259-270. (doi:10.1530/reprod/125.2.259)

Armstrong DG, Gong JG \& Webb R 2003 Interactions between nutrition and ovarian activity in cattle: physiological, cellular and molecular mechanisms. Reproduction Supplements 61 403-414.

Bazer FW, Wu G, Johnson GA, Kim J \& Song G 2011 Uterine histotroph and conceptus development: select nutrients and secreted phosphoprotein 1 affect mechanistic target of rapamycin cell signaling in ewes. Biology of Reproduction 85 1094-1107. (doi:10.1095/biolreprod.111.094722)

Beal WE, Short RE, Staigmiller RB, Bellows RA, Kaltenbach CC \& Dunn TG 1978 Influence of dietary energy intake on bovine pituitary and luteal function. Journal of Animal Science 46 181-188. (doi:10.2527/ jas1978.461181x)

Beckman JD, Grazul-Bilska AT, Johnson ML, Reynolds LP \& Redmer DA 2006 Isolation and characterization of ovine luteal pericytes and effects of nitric oxide on pericyte expression of angiogenic factors. Endocrine 29 467-476. (doi:10.1385/ENDO:29:3:467)

Berisha B, Schams D, Kosmann M, Amselgruber W \& Einspanier R 2000 Expression and tissue concentration of vascular endothelial growth factor, its receptors, and localization in the bovine corpus luteum during estrous cycle and pregnancy. Biology of Reproduction 63 1106-1114. (doi:10.1095/biolreprod63.4.1106)

Berisha B, Schams D, Rodler D \& Pfaffl MW 2016 Angiogenesis in the ovary - the most important regulatory event for follicle and corpus luteum development and function in cow - an overview. Anatomia Histologia Embryologia 45 124-130. (doi:10.1111/ahe.12180)

Boiti C, Zampini D, Guelfi G, Paolocci F, Zerani M \& Gobbetti A 2002 Expression patterns of endothelial and inducible nitric oxide synthase isoforms in corpora lutea of pseudopregnant rabbits at different luteal stages. Journal of Endocrinology 173 285-296. (doi:10.1677/ joe.0.1730285)

Bradford AP, Jones K, Kechris K, Chosich J, Montague M, Warren WC, May MC, Al-Safi Z, Kuokkanen S, Appt SE \& Polotsky AJ 2015 Joint MiRNA/mRNA expression profiling reveals changes consistent with development of dysfunctional corpus luteum after weight gain. PLoS ONE 10 e0135163. (doi:10.1371/journal.pone.0135163)

Christenson LK \& Stouffer RL 1996 Proliferation of microvascular endothelial cells in the primate corpus luteum during the menstrual cycle and simulated early pregnancy. Endocrinology 137 367-374. (doi:10.1210/endo.137.1.8536637)
Clarkson P, Adams MR \& Powe AJ 1996 Oral L-arginine improves endothelium-dependent dilation in hypercholesterolemic young adults. Journal of Clinical Investigation 97 1989-1994. (doi:10.1172/JCI118632) Cooke JP, Singer AH, Tsao P, Zera P, Rowan RA \& Billingham ME 1992 Antiatherogenic effects of $\mathrm{L}$-arginine in the hypercholesterolemic rabbit. Journal of Clinical Investigation 90 1168-1172. (doi:10.1172/JCI115937)

Creager MA, Gallagher SJ, Girerd XJ, Coleman SM, Dzau VJ \& Cooke JP 1992 L-arginine improves endothelium-dependent vasodilation in hypercholesterolemic humans. Journal of Clinical Investigation $\mathbf{9 0}$ 1248-1253. (doi:10.1172/JCI115987)

Cumming IA, Brown JA, Blockley MA, Winfield CG, Baxter R \& Goding JR 1971 Constancy of interval between luteinizing hormone release and ovulation in the ewe. Journal of Reproduction and Fertility 24 134-135. (doi:10.1530/jrf.0.0240134)

de Boo HA, van Zijl PL, Smith DE, Kulik W, Lafeber HN \& Harding JE 2005 Arginine and mixed amino acids increase protein accretion in the growthrestricted and normal ovine fetus by different mechanisms. Pediatric Research 58 270-277. (doi:10.1203/01.PDR.0000169977.48609.55)

Diaz FJ, Anderson LE, Wu YL, Rabot A, Tsai SJ \& Wiltbank MC 2002 Regulation of progesterone and prostaglandin F-2 alpha production in the CL. Molecular and Cellular Endocrinology 191 65-80. (doi:10.1016/ S0303-7207(02)00056-4)

Diskin MG, Mackey DR, Roche JF \& Sreenan JM 2003 Effects of nutrition metabolic status on circulating hormones and ovarian follicle development in cattle. Animal Reproduction Science 78 345-370. (doi:10.1016/S0378-4320(03)00099-X)

Dixit DA \& Parvizi N 2001 Nitric oxide and the control of reproduction. Animal Reproduction Science 65 1-16. (doi:10.1016/S03784320(00)00224-4)

Dong YL, Gangula RR, Tang L \& Yallampalli L 1999 Nitric oxide reverses prostaglandin induced inhibition in ovarian progesterone secretion in rats. Human Reproduction 14 27-32. (doi:10.1093/humrep/14.1.27)

Dong JY, Qin LQ, Zhang Z, Zhao Y, Wang J, Arigoni F \& Zhang W 2011 Effect of arginine supplementation on blood pressure: a meta-analysis of randomized, double-blind, placebo-controlled trials. American Heart Journal 162 959-965. (doi:10.1016/j.ahj.2011.09.012)

Doraiswamy V, Knudson DL, Grazul-Bilska AT, Redmer DA \& Reynolds LP 1998 Fibroblast growth factor receptor (FGFR)-1 and -2 in the ovine corpus luteum throughout the estrous cycle. Growth Factors $\mathbf{1 6}$ 125-135. (doi:10.3109/08977199809002123)

Duda DG, Fukumura D \& Jain RK 2004 Role of eNOS in neovascularization: $\mathrm{NO}$ for endothelial progenitor cells. Trends in Molecular Medicine 10 143-145. (doi:10.1016/j.molmed.2004.02.001)

Eborn DR, Cushman RA \& Echternkamp SE 2013 Effect of postweaning diet on ovarian development and fertility in replacement beef heifers. Journal of Animal Sciences 91 4168-4179. (doi:10.2527/jas.2012-5877)

Ferrara N \& Davis-Smyth T 1997 The biology of vascular endothelial growth factor. Endocrine Reviews 18 4-25. (doi:10.1210/edrv.18.1.0287)

Ferrara N, Chen H, Davis-Smyth T, Gerber HP, Nguyen TN, Peers D, Chisholm V, Hillan KJ \& Schwall RH 1998 Vascular endothelial growth factor is essential for corpus luteum angiogenesis. Nature Medicine $\mathbf{4}$ 336-340. (doi:10.1038/nm0398-336)

Fiorito C, Balestrieri ML, Crimi E, Giovane A, Grimaldi V, Minucci PB, Servillo L, D'Armiento FP \& Farzati B, Napoli C 2008 Effect of L-arginine on circulating endothelial progenitor cells and VEGF after moderate physical training in mice. International Journal of Cardiology 126 421-423. (doi:10.1016/j.ijcard.2007.12.004)

Fisher TE, Molskness TA, Villeda A, Zelinski MB, Stouffer RL \& Xu J 2013 Vascular endothelial growth factor and angiopoietin production by primate follicles during culture is a function of growth rate, gonadotrophin exposure and oxygen milieu. Human Reproduction 28 3263-3270. (doi:10.1093/humrep/det337)

Fraser HM, Dickson SE, Lunn SF, Wulff C, Morris KD, Carroll VA \& Bicknell R 2000 Suppression of luteal angiogenesis in the primate after neutralization of vascular endothelial growth factor. Endocrinology 141 995-1000. (doi:10.1210/en.141.3.995)

Friden EB, Runessen E \& Hahlin M 2000 Evidence for nitric oxide acting as a luteolytic factor in the human corpus luteum. Molecular Human Reproduction 6 397-403. (doi:10.1093/molehr/6.5.397)

Galeati G, Forni M, Spinaci M, Zannoni A, Govoni N, Ribeiro LA, Seren E \& Tamanini C 2005 Fasting influences steroidogenesis, vascular endothelial growth factor (VEGF) levels and mRNAs expression for VEGF, VEGF receptor type 2 (VEGFR-2), endothelin-1 (ET-1), endothelin 
receptor type A (ET-A) and endothelin converting enzyme-1 (ECE-1) in newly formed pig corpora lutea. Domestic Animal Endocrinology 28 272-284. (doi:10.1016/j.domaniend.2004.11.002)

Girerd XJ, Hirsch AT, Cooke JP, Dzau VJ \& Creager MA 1990 L-arginine augments endothelial dependent vasodilation in cholesterol-fed rabbits. Circulation Research 67 1301-1308. (doi:10.1161/01.RES.67.6.1301)

Geva E \& Jaffe RB 2000 Role of vascular endothelial growth factor in ovarian physiology and pathology. Fertility and Sterility 74 429-438. (doi:10.1016/S0015-0282(00)00670-1)

Gombe S \& Hansel W 1973 Plasma luteinizing hormone (LH) and progesterone levels in heifers on restricted energy intakes. Journal of Animal Science 37 728-733. (doi:10.2527/jas1973.373728x)

Grazul-Bilska AT, Redmer DA \& Reynolds LP 2001 Growth factors during ovarian angiogenesis. In Vascular Morphogenesis in the Female Reproductive System, pp 131-147. Eds H G Augustin, M L Iruela-Arispe, PAW Rogers \& SK Smith. Boston, MA, USA: Birkhauser.

Grazul-Bilska AT, Navanukraw C, Johnson ML, Arnold DA, Reynolds LP \& Redmer DA 2006 Expression of endothelial nitric oxide synthase (eNOS) in the ovine ovary throughout the estrous cycle. Reproduction 132 579-587. (doi:10.1530/REP-06-0009)

Grazul-Bilska AT, Caton JS, Arndt W, Burchill K, Thorson C, Borowczyk E, Bilski J, Redmer DA, Reynolds LP \& Vonnahme KA 2009 Cellular proliferation and vascularization in ovine fetal ovaries: effects of undernutrition and selenium in maternal diet. Reproduction 137 699-707. (doi:10.1530/REP-08-0375)

Grazul-Bilska AT, Borowicz PP, Johnson ML, Minten MA, Bilski J, Wroblewski R, Redmer DA \& Reynolds LP 2010 Placental development during early pregnancy in sheep: vascular growth and expression of angiogenic factors in maternal placenta. Reproduction 140 165-174. (doi:10.1530/REP-09-0548)

Grazul-Bilska AT, Johnson ML, Borowicz PP, Minten M, Bilski J, Wroblewski R, Velimirovich M, Coupe LR, Redmer DA \& Reynolds LP 2011 Placental development during early pregnancy in sheep: cell proliferation, global methylation and angiogenesis in fetal placenta. Reproduction 141 529-540. (doi:10.1530/REP-10-0505)

Grazul-Bilska AT, Borowczyk E, Bilski JJ, Reynolds LP, Redmer DA, Caton JS \& Vonnahme KA 2012 Overfeeding and underfeeding have detrimental effects on oocyte quality measured by in vitro fertilization and early embryonic development in sheep. Domestic Animal Endocrinology 43 289-298. (doi:10.1016/j.domaniend.2012.05.001)

Grazul-Bilska AT, Johnson ML, Borowicz PP, Baranko L, Redmer DA \& Reynolds LP 2013 Placental development during early pregnancy in sheep: Effects of embryo origin on fetal and placental growth and global methylation. Theriogenology 79 94-102. (doi:10.1016/j. theriogenology.2012.09.013)

Grazul-Bilska AT, Neville TL, Borowczyk E, Sharma A, Reynolds LP, Caton JS, Redmer DA \& Vonnahme KA 2014 Ovarian and uterine characteristics and onset of puberty in adolescent offspring: effects of maternal diet and Se supplementation in sheep. Theriogenology $\mathbf{8 1}$ 887-895. (doi:10.1016/j.theriogenology.2013.12.024)

Grazul-Bilska AT, Bass CS, Kaminski SL, Perry G \& Redmer DA 2015 Secretion of progesterone by ovine granulosa cells: effects of nitric oxide and plane of nutrition. Canadian Journal of Physiology and Pharmacology 93 973-978. (doi:10.1139/cjpp-2015-0050)

Gunn RG \& Doney JM 1975 The interaction of nutrition and body condition score at mating on ovulation rate and early embryo mortality in Scottish Blackface ewes. Journal of Agricultural Science 85 465-470. (doi:10.1017/S0021859600062341)

Hallemeesch MM, Lamers WH \& Deutz NE 2002 Reduced arginine availability and nitric oxide production. Clinical Nutrition 21 273-279. (doi:10.1054/clnu.2002.0571)

Hamudikuwanda H, Gallo G, Block E \& Downey BE 1996 Adipose tissue progesterone concentrations in dairy cows during late pregnancy and early lactation. Animal Reproduction Science 43 15-23. (doi:10.1016/0378-4320(96)01468-6)

Hardy TA \& May JM 2002 Coordinate regulation of L-arginine uptake and nitric oxide synthase activity in cultured endothelial cells. Free Radical Research Communication 32 122-131. (doi:10.1016/S08915849(01)00781-X)

Hazzard TM, Xu FH \& Stouffer RL 2002 Injection of soluble vascular endothelial growth factor receptor 1 into the preovulatory follicle disrupts ovulation and subsequent luteal function in rhesus monkeys. Biology of Reproduction 67 1305-1312. (doi:10.1095/biolreprod67.4.1305)
Hoeben A, Landuyt B, Highley MS, Wildiers H, Van Oosterom AT \& De Bruijn EA 2004 Vascular endothelial growth factor and angiogenesis. Pharmacological Review 56 549-580. (doi:10.1124/pr.56.4.3)

Hünigen H, Bisplinghoff P, Plendl J \& Bahramsoltani M 2008 Vascular dynamics in relation to immunolocalisation of VEGF-A, VEGFR-2 and Ang-2 in the bovine corpus luteum. Acta Histochemica 110 462-472. (doi:10.1016/j.acthis.2008.02.006)

Hussain MA, Abogresha NM, Hassan R, Tamany DA \& Lotfy M 2016 Effect of feeding a high-fat diet independently of caloric intake on reproductive function in diet-induced obese female rats. Archives of Medical Sciences 12 906-914. (doi:10.5114/aoms.2016.59790)

Hurwitz A, Finci-Yeheskel Z, Milwidsky A \& Mayer M 2002 Regulation of cyclooxygenase activity and progesterone production in the rat corpus luteum by inducible nitric oxide synthase. Reproduction 123 663-669. (doi:10.1530/rep.0.1230663)

Jablonka-Shariff A \& Olson LM 1997 Hormonal regulation of nitric oxide synthases and their cell-specific expression during follicular development in the rat ovary. Endocrinology 138 460-468. (doi:10.1210/ en.138.1.460)

Jablonka-Shariff A, Grazul-Bilska AT, Redmer DA \& Reynolds LP 1993 Growth and cellular proliferation of ovine corpora lutea throughout the ovine estrous cycle. Endocrinology 133 1871-1879. (doi:10.1210/ en.133.4.1871)

Jablonka-Shariff A, Grazul-Bilska AT, Redmer DA \& Reynolds LP 1997 Cellular proliferation and fibroblast growth factors in the corpus luteum during early pregnancy in ewes. Growth Factors 14 15-23. (doi:10.3109/08977199709021507)

Jaroszewski JJ, Skarzynski DJ \& Okuda K 2001 Nitric oxide as a local regulator in the mammalian ovary. In Reproductive Biotechnology: Reproductive Biotechnology Update and Its Related Physiology, pp 105-112. Eds H Miyamoto \& N Manabe. Tokyo, Japan: Elsevier.

Jaroszewski JJ, Bogacki M \& Skarzynski DJ 2003 Progesterone production in bovine luteal cells treated with drugs that modulate nitric oxide production. Reproduction 125 389-395. (doi:10.1530/rep.0.1250389)

Johnson MC, Diaz HA, Stocco C, Palomino A, Devoto L \& Vega M 1999 Antisteroidogenic action of nitric oxide on human corpus luteum in vitro: mechanism of action. Endocrine 11 31-36. (doi:10.1385/ ENDO:11:1:31)

Jordan ER \& Swanson LV 1979 Serum progesterone and luteinizing hormone in dairy cattle fed varying levels of crude protein. Journal of Animal Science 48 1154-1158. (doi:10.2527/jas1979.4851154x)

Kaczmarek MM, Kowalczyk AE, Waclawik A, Schams D \& Ziecik AJ 2007 Expression of vascular endothelial growth factor and its receptors in the porcine corpus luteum during the estrous cycle and early pregnancy. Molecular Reproduction and Development 74 730-739. (doi:10.1002/ mrd.20638)

Kaminski SL, Redmer DA, Bass CS, Keisler DH, Vonnahme KA, Dorsam ST \& Grazul-Bilska AT 2015 The effects of diet and arginine treatment on serum metabolites and selected hormones during the estrous cycle in sheep. Theriogenology 83 808-816. (doi:10.1016/j. theriogenology.2014.11.017)

Keator CS, Schreiber DT, Hoagland TA \& McCracken JA 2008 Luteotrophic and luteolytic effects of nitric oxide in sheep are dose-dependent in vivo. Domestic Animal Endocrinology 35 74-80. (doi:10.1016/j. domaniend.2008.02.001)

Keisler DH \& Buckrell BC 1997 Breeding strategies. In: Current Therapy in Large Animal Theriogenology, pp 603-611. Ed RS Youngquist. Philadelphia, PA, USA: WB Saunders Company.

Knickerbocker J, Wiltbank MC \& Niswender GD 1988 Mechanisms of luteolysis in domestic livestock. Domestic Animal Endocrinology 5 91-107. (doi:10.1016/0739-7240(88)90011-2)

Lassala A, Bazer FW, Cudd TA, Datta S, Keisler DH, Satterfield MC, Spencer TE \& Wu G 2010 Parenteral administration of L-arginine prevents fetal growth restriction in undernourished ewes. Journal of Nutrition 140 1242-1248. (doi:10.3945/jn.110.125658)

Lassala A, Bazer FW, Cudd TA, Datta S, Keisler DH, Satterfield MC, Spencer TE \& Wu G 2011 Parenteral administration of L-arginine enhances fetal survival and growth in sheep carrying multiple fetuses. Journal of Nutrition 141 849-855. (doi:10.3945/jn.111.138172)

Lassoued N, Rekik M, Mahouachi M \& Ben Hamouda M 2004 The effect of nutrition prior to and during mating on ovulation rate, reproductive wastage, and lambing rate in three sheep breeds. Small Ruminant Research 52 117-125. (doi:10.1016/S0921-4488(03)00250-5) 
Lents CA, Randel RD, Stelzleni AM, Caldwell LC \& Welsh TH Jr 2011 Function of the corpus luteum in beef heifers is affected by acute submaintenance feeding but is not correlated with residual feed intake. Journal of Animal Sciences 12 4023-4031. (doi:10.2527/jas.2011-4097)

Liu XD, Wu X, Yin YL, Liu YQ, Geng MM, Yang HS, Blachier F \& Wu GY 2012 Effects of dietary L-arginine or $\mathrm{N}$-carbamylglutamate supplementation during late gestation of sows on the miR-15b/16, miR-221/222, VEGFA and eNOS expression in umbilical vein. Amino Acids 42 2111-2119. (doi:10.1007/s00726-011-0948-5)

Livak KJ \& Schmittgen TD 2001 Analysis of relative gene expression data using real-time quantitative PCR and the 2(-Delta Delta $\mathrm{C}(\mathrm{T})$ ) Method. Methods 25 402-408. (doi:10.1006/meth.2001.1262)

Luther JS, Windorski EJ, Caton JS, Wu G, Kirsch JD, Vonnahme KA, Reynolds LP \& Schauer CS 2009 Effects of arginine supplementation on reproductive performance in Rambouillet ewes. https://www.ag.ndsu. edu/Hettingerrec/sheep/individual-articles-from-2009-sheep-researchreport/Effects \%20of\%20arginine \%20supplementation \%20on $\% 20$ reproductive\%20performance.pdf

Mateo RD, Wu G \& Bazer FW 2007 Dietary L-arginine supplementation enhances the reproductive performance of gilts. Journal of Nutrition 137 652-656.

Mitsube K, Mikuni M, Matouse M \& Brännström M 1999 Effects of a nitric oxide donorand nitric oxide synthase inhibitors on luteinizing hormone-induced ovulation in the ex-vivo perfused rat ovary. Human Reproduction 14 2537-2543. (doi:10.1093/humrep/14.10.2537)

Moran LJ, Noakes M, Clifton PM \& Norman RJ 2010 The effect of modifying dietary protein and carbohydrate in weight loss on arterial compliance and postprandial lipidemia in overweight women with polycystic ovary syndrome. Fertility and Sterility 94 2451-2454. (doi:10.1016/j. fertnstert.2010.02.057)

Morris SM Jr \& Billiar TR 1994 New insights into the regulation of induced nitric oxide synthesis. American Journal of Physiology 266 E829-E839.

Motta AB, Estevez A \& de Gimeno MF 1999 The involvement of nitric oxide in corpus luteum regression in the rat: feedback mechanism between prostaglandin F2 $\alpha$ and nitric oxide. Molecular Human Reproduction $\mathbf{5}$ 1011-1016. (doi:10.1093/molehr/5.11.1011)

Motta AB, Estevez A, Tognetti M, de Gimeno MF \& Franchi AM 2001 Dual effects of nitric oxide in functional and regressing rat corpus luteum. Molecular Human Reproduction 7 43-47. (doi:10.1093/molehr/7.1.43)

Müller K, Ellenberger C \& Schoon HA 2009 Histomorphological and immunohistochemical study of angiogenesis and angiogenic factors in the ovary of the mare. Research in Veterinary Sciences 87 421-431. (doi:10.1016/j.rvsc.2009.04.011)

Niswender GD 2002 Molecular control of luteal secretion of progesterone. Reproduction 123 333-339. (doi:10.1530/rep.0.1230333)

Niswender GD \& Nett TM 1994 Corpus luteum and its control in infraprimate species. In The Physiology of Reproduction, edn 2, pp 781815. Eds E Knobil \& JD Neil. New York, NY, USA: Raven Press.

O'Callaghan D \& Boland MP 1999 Nutritional effects on ovulation, embryo development and the establishment of pregnancy in ruminants. Animal Science 68 299-314. (doi:10.1017/s1357729800050311)

Papa PC, Moura CE, Artoni LP, Fatima LA, Campos DB, Marques JE, Baruselli PS Jr, Binelli M, Pfarrer C \& Leiser R 2006 VEGF system expression in different stages of estrous cycle in the corpus luteum of non-treated and superovulated water buffalo. Domestic Animal Endocrinology 29 329-339.

Parr RA, Davis IF, Fairclough RJ \& Miles MA 1987 Overfeeding during early pregnancy reduces peripheral progesterone concentration and pregnancy rate in sheep. Journal of Reproduction and Fertility $\mathbf{8 0}$ 317-320. (doi:10.1530/jrf.0.0800317)

Palloshi A, Fragasso G, Piatti P, Monti LD, Setola E, Valsecchi G, Galluccio E, Chierchia SL \& Margonato A 2004 Effect of oral L-arginine on blood pressure and symptoms and endothelial function in patients with systemic hypertension, positive exercise tests, and normal coronary arteries. American Journal of Cardiology 93 933-935. (doi:10.1016/j. amjcard.2003.12.040)

Rajapakse NW \& Mattson DL 2009 Role of L-arginine in nitric oxide production in health and hypertension. Clinical and Experimental Pharmacology and Physiology 36 249-255. (doi:10.1111/j.14401681.2008.05123.x)

Redmer DA, Dai Y, Li J, Charnock-Jones DS, Smith SK, Reynolds LP \& Moor RM 1996 Characterization and expression of vascular endothelial growth factor (VEGF) in the ovine corpora luteum. Journal of Reproduction and Fertility 108 157-165. (doi:10.1530/jrf.0.1080157)

Redmer DA, Doraiswamy V, Bortnem BJ, Fisher K, Jablonka-Shariff A, Grazul-Bilska AT \& Reynolds LP 2001 Evidence for a role of capillary pericytes in vascular growth of thedeveloping ovine corpus luteum. Biology of Reproduction 65 879-889. (doi:10.1095/biolreprod65.3.879)

Redmer DA, Aitken RP, Milne JS, Reynolds LP \& Wallace JM 2005 Influence of maternal nutrition on messenger RNA expression of placental angiogenic factors and their receptors at midgestation in adolescent sheep. Biology of Reproduction 72 1004-1009. (doi:10.1095/ biolreprod.104.037234)

Redmer DA, Dorsam ST, Grazul-Bilska AT \& Borowicz PP 2013 A fluorescent staining technique for studying vascularity and angiogenesis in interdigitated maternal and fetal villi of sheep placenta. The FASEB conference, Abstract.

Reynolds LP, Grazul-Bilska AT, Killilea SD \& Redmer DA 1994 Mitogenic factors of corpora lutea. Progress in Growth Factor Research 5 159-175. (doi:10.1016/0955-2235(94)90003-5)

Reynolds LP, Grazul-Bilska AT \& Redmer DA 2000 Angiogenesis in the corpus luteum. Endocrine Reviews 12 1-9. (doi:10.1385/ENDO:12:1:1)

Reynolds LP, Grazul-Bilska AT \& Redmer DA 2002 Angiogenesis in the female reproductive system: pathological implications. Review Article. International Journal of Experimental Pathology 83 151-163. (doi:10.1046/j.1365-2613.2002.00277.x)

Rhind SM, Martin GB, McMillen S, Tsonis CG \& McNeilly AS 1989 Effect of level of food intake of ewes on the secretion of LH and FSH and on the pituitary response to gonadotrophin-releasing hormone in ovariectomized ewes. Journal of Endocrinology 121 325-330. (doi:10.1677/joe.0.1210325)

Rodrigues RO, Trevisanuto C, Cooke RF \& Vasconcelos JL 2011 Effects of body weight loss on serum progesterone concentrations of nonlactating dairy cows. Theriogenology 75 131-137. (doi:10.1016/j. theriogenology.2010.07.018)

Saevre CB, Caton JS, Luther JS, Meyer AM, Dhuyvetter DV, Musser RE, Kirsch JD, Kapphahn M, Redmer DA \& Schauer CJ 2011a Effects of rumen-protected arginine supplementation on ewe serum-amino-acid concentration, circulating progesterone, and ovarian blood flow. Sheep and Goat Research Journal 26 8-12.

Saevre CB, Meyer AM, Van Emon ML, Redmer DA, Caton JS, Kirsch JD, Luther JS \& Schauer CS 2011 Impacts of arginine on ovarian function and reproductive performance at the time of maternal recognition of pregnancy in ewes. https://www.ag.ndsu.edu/hettingerrec/sheep/ individual-articles-from-2011-sheep-research-report/Impacts $\% 20$ of $\% 20$ arginine $\% 20$ on $\% 20$ ovarian $\% 2$ function $\% 2$ and $\% 20$ reproductive.pdf

Scalera F, Closs EI, Flick E, Martens-Lobenhoffer J, Boissel JP, Lendeckel U, Heimburg A \& Bode-Böger SM 2009 Paradoxical effect of L-arginine: acceleration of endothelial cell senescence. Biochemical and Biophysical Research Communications 386 650-655. (doi:10.1016/j. bbrc.2009.06.091)

Scaramuzzi RJ, Campbell BK, Downing JA, Kendall NR, Khalid M, MunozGutierrez M \& Somchit A 2006 A review of the effects of supplementary nutrition in the ewe on the concentrations of reproductive and metabolic hormones and the mechanisms that regulate folliculogenesis and ovulation rate. Reproduction Nutrition Development 46 339-354. (doi:10.1051/rnd:2006016)

Skarzynski DJ \& Okuda K 2000 Different actions of noradrenaline and nitric oxide on the output of prostaglandins and progesterone in cultured bovine luteal cells. Prostaglandins and Other Lipid Mediators 60 35-47. (doi:10.1016/S0090-6980(99)00046-5)

Skarzynski DJ, Kobayashi S \& Okuda K 2000 Influence of nitric oxide and noradrenaline on prostaglandin PGF2-induced oxytocin secretion and intracellular calcium mobilization in cultured bovine luteal cells. Biology of Reproduction 63 1000-1005. (doi:10.1095/biolreprod63.4.1000)

Skarzynski DJ, Jaroszewski JJ, Bah MM, Deptula KM, Barszczewska B, Gawronska B \& Hansel W 2003 Administration of a nitric oxide synthase inhibitor counteracts prostaglandin $F_{2}$-induced luteolysis in cattle. Biology of Reproduction 68 1674-1681. (doi:10.1095/ biolreprod.102.008573)

Smith JF 1995 Protein, energy, and ovulation rate. In Genetics of Reproduction in Sheep, pp 349-59. Eds RB Land \& DW Robinson. London, UK: Butterworth. 
Stabenfeldt GH, Holt JA \& Ewing LL 1969 Peripheral plasma progesterone levels during the ovine estrous cycle. Endocrinology 85 11-15. (doi:10.1210/endo-85-1-11)

Stouffer RL \& Hennebold JD 2015 Structure, function and regulation of the corpus luteum. In The Knobil and Neill's Physiology of Reproduction, edn 4, pp 1023-1076. Eds TM Plant \& AJ Zeleznik. New York, NY, USA: Academic Press as an imprint of Elsevier.

Sugino N, Kashida S, Takiguchi S, Karube A \& Kato H 2000 Expression of vascular endothelial growth factor and its receptors in the human corpus luteum during the menstrual cycle and in early pregnancy. Journal of Clinical Endocrinology and Metabolism 85 3919-3924. (doi:10.1210/ jc.85.10.3919)

Thomson RL, Brinkworth GD, Noakes M, Clifton PM, Norman RJ \& Buckley JD 2012 The effect of diet and exercise on markers of endothelial function in overweight and obese women with polycystic ovary syndrome. Human Reproduction 27 2169-2176. (doi:10.1093/ humrep/des138)

van der Zee R, Murohara T, Luo Z, Zollmann F, Passeri J, Lekutat C \& Isner JM 1997 Vascular endothelial growth factor/vascular permeability factor augments nitric oxide release from quiescent rabbit and human vascular endothelium. Circulation 18 1030-1037. (doi:10.1161/01. cir.95.4.1030)

Vega M, Johnson MC, Díaz HA, Urrutia LR, Troncoso JL \& Devoto L 1998 Regulation of human luteal steroidogenesis in vitro by nitric oxide. Endocrine 8 185-191. (doi:10.1385/ENDO:8:2:185)

Vega M, Urrutia L, Iñiguez G, Gabler F, Devoto L \& Johnson MC 2000 Nitric oxide induces apoptosis in the human corpus luteum in vitro. Molecular Human Reproduction 6 681-687. (doi:10.1093/ molehr/6.8.681)

Vonnahme KA, Redmer DA, Borowczyk E, Bilski JJ, Luther JS, Johnson ML, Reynolds LP \& Grazul-Bilska AT 2006 Vascular composition, apoptosis, and expression of angiogenic factors in the corpus luteum during prostaglandin F2alpha-induced regression in sheep. Reproduction 131 1115-1126. (doi:10.1530/rep.1.01062)

Webb R, Garnsworthy PC, Gong JG \& Armstrong DG 2004 Control of follicular growth: local interactions and nutritional influences. Journal of Animal Science 82 E63-E74.

Webb R, Garnsworthy PC, Campbell BK \& Hunter MG 2007 Intraovarian regulation of follicular development and oocyte competence in farm animals. Theriogenology 68 S22-S29. (doi:10.1016/j. theriogenology.2007.04.036)

Weems YS, Lennon E, Uchima T, Raney A, Goto K, Ong A, Zaleski H \& Weems CW 2005 Is nitric oxide luteolytic or antiluteolytic?
Prostaglandins and Other Lipid Mediators 78 129-138. (doi:10.1016/j. prostaglandins.2005.06.002)

Wu G \& Morris SM Jr 1998 Arginine metabolism: nitric oxide and beyond. Biochemistry Journal 336 1-17. (doi:10.1042/bj3360001)

Wu G \& Meininger CJ 2002 Arginine metabolism: nitric oxide and beyond. Annual Review of Nutrition 22 61-86. (doi:10.1146/annurev. nutr.22.110901.145329)

Wu G, Flynn NE, Flynn SP, Jolly CA \& Davis PK 1999 Dietary protein or arginine deficiency impairs constitutive and inducible nitric oxide synthesis by young rats. Journal of Nutrition 129 1347-1154.

Xiong Y, Fru MF, Yu Y, Montani JP, Ming XF \& Yang Z 2014 Long term exposure to $\mathrm{L}$-arginine accelerates endothelial cell senescence through arginase-II and S6K1 signaling. Aging 6 369-379. (doi:10.18632/ aging.100663)

Xu Z, McDonald MF \& McCutheon SN 1989 The effects of nutritionallyinduced live weight differences on follicular development, ovulation rate, oestrus activity, and plasma follicle stimulating hormone levels in ewe. Animal Reproduction Science 19 67-78. (doi:10.1016/03784320(89)90047-X)

Yoshioka S, Abe H, Sakumoto R \& Okuda K 2013 Proliferation of luteal steroidogenic cells in cattle. PLoS ONE 12 e84186. (doi:10.1371/ journal.pone.0084186)

Young FM, Rodger FE, Illingworth PJ \& Fraser HM 2000 Cell proliferation and vascular morphology in the marmoset corpus luteum. Human Reproduction 3 557-566. (doi:10.1093/humrep/15.3.557)

Zackrisson U, Mikuni M \& Wallin A 1996 Cell-specific localization of nitric oxide synthase (NOS) in the rat ovary during follicular development, ovulation and luteal formation. Human Reproduction 11 2667-2274. (doi:10.1093/oxfordjournals.humrep.a019189)

Zeng XF, Wang FL, Fan X, Yang WJ, Zhou B, Li PF, Yin YL, Wu G \& Wang JJ 2008 Dietary arginine supplementation during early pregnancy enhances embryonic survival in rats. Journal of Nutrition 138 1421-1425.

Zerani M, Catone G, Betti G \& Parillo F 2013 Immunopresence and functional activity of prostaglandin-endoperoxide synthases and nitric oxide synthases in bovine corpora lutea during diestrus. Folia Morphologica 72 36-40. (doi:10.5603/FM.2013.0006)

Received 12 September 2016

First decision 19 September 2016

Revised manuscript received 15 November 2016

Accepted 29 November 2016 